\title{
Modeling pollution potential input from the drainage basin into Barra Bonita reservoir, São Paulo - Brazil
}

\author{
Prado, RB. ${ }^{a *}$ and Novo, EMLM. ${ }^{b}$ \\ ${ }^{\text {a} E m b r a p a ~ S o l o s ~-~ C N P S, ~ R u a ~ J a r d i m ~ B o t a ̂ n i c o, ~ 1024, ~ J a r d i m ~ B o t a ̂ n i c o, ~ R i o ~ d e ~ J a n e i r o, ~ R J, ~ B r a z i l ~}$

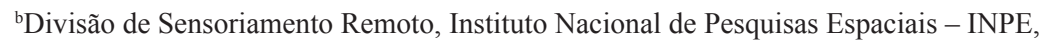 \\ Av. dos Astronautas, 1758, CP 515, CEP 12201-970, Jardim da Granja, São José dos Campos, SP, Brazil \\ *e-mail: rachel.prado@embrapa.br
}

Received: July 16, 2013 - Accepted: October 31, 2013 - Distributed: May 31, 2015

(With 4 figures)

\begin{abstract}
In this study multi-criteria modeling tools are applied to map the spatial distribution of drainage basin potential to pollute Barra Bonita Reservoir, São Paulo State, Brasil. Barra Bonita Reservoir Basin had undergone intense land use/land cover changes in the last decades, including the fast conversion from pasture into sugarcane. In this respect, this study answers to the lack of information about the variables (criteria) which affect the pollution potential of the drainage basin by building a Geographic Information System which provides their spatial distribution at sub-basin level. The GIS was fed by several data (geomorphology, pedology, geology, drainage network and rainfall) provided by public agencies. Landsat satellite images provided land use/land cover map for 2002. Ratings and weights of each criterion defined by specialists supported the modeling process. The results showed a wide variability in the pollution potential of different sub-basins according to the application of different criterion. If only land use is analyzed, for instance, less than $50 \%$ of the basin is classified as highly threatening to water quality and include sub basins located near the reservoir, indicating the importance of protection areas at the margins. Despite the subjectivity involved in the weighing processes, the multi-criteria analysis model allowed the simulation of scenarios which support rational land use polices at sub-basin level regarding the protection of water resources.
\end{abstract}

Keywords: geotechnology, water quality, nonpoint pollution, multi-criteria analysis, watershed management.

\section{Modelagem do potencial de contribuição da bacia de drenagem para a poluição da qualidade da água do reservatório de Barra Bonita, São Paulo - Brasil}

\section{Resumo}

Este estudo aplica ferramentas de modelagem multicritério para mapear a distribuição espacial do potencial de contribuição da bacia de drenagem para a poluição do reservatório de Barra Bonita, Estado de São Paulo, Brasil. A bacia de drenagem Barra Bonita passou por intensas alterações no uso e cobertura da terra, incluindo um rápido aumento na conversão de pastagens em cana-de-açúcar nas últimas décadas. Assim sendo, este estudo contribui com a demanda de informação sobre os fatores (critérios) que afetam o potencial de poluição das bacias de drenagem através da construção de um Sistema de Informação Geográfica (SIG), com sua distribuição espacial ao nível de sub-bacia. A base de dados foi alimentada por diversos órgãos públicos, que forneceram informações georreferenciadas sobre a geomorfologia da bacia de drenagem, pedologia, geologia, rede de drenagem e precipitação. Imagens do satélite Landsat e ferramentas de geoprocessamento permitiram a obtenção do mapa de uso e cobertura da terra referente ao ano de 2002. Especialistas definiram as classificações e pesos de cada critério subsidiando o processo da modelagem. Obteve-se que o potencial sub-bacia para poluir o reservatório varia amplamente de um critério para o outro. Se somente o uso da terra for analisado, por exemplo, menos de $50 \%$ da área da bacia é classificada como tendo alto potencial de poluição da água do reservatório em questão. Essa área de alto potencial, nesse caso está associada às regiões mais próximas ao reservatório, indicando ser crucial a criação de áreas e preservação em sub-bacias próximas às margens do reservatório. Apesar da subjetividade envolvida no processo de ponderação, a análise multi-critério utilizada nesta pesquisa mostrou ser uma importante ferramenta para simulação de cenários que possam fornecer suporte às políticas de ordenamento e uso adequado da terra em nível de sub-bacia, visando à proteção dos recursos hídricos.

Palavras-chave: geotecnologia, qualidade da água, poluição difusa, análise multicritérios, gestão de bacias hidrográficas. 


\section{Introduction}

The importance of water for life has been recognized since early civilizations which flourished nearby rivers with abundance of water for agriculture, fishing and transportation. However, as society became more technically sophisticated, water awareness vanished (Falkenmark and Widstrand, 1992) and the ideas of water availability as limitless became conventional. As a consequence, up to late 1990's water conservation practices were not enforced.

Nowadays, water shortage threatens humanity because it is not only essential for direct human consumption but also it is vital for supporting life on Earth. The water cycle is crucial for plant's life support system because water and biota is interlinked to an extent that accounts for the regulation of Earth's surface temperatures. Besides, the water cycle is a link between air, land and sea. Any unbalance in the functioning of one component may cause undesirable changes to the entire planet (WWAP, 2012; World Bank, 2010).

In addition, water is an essential natural resource that shapes regional landscapes and is vital for ecosystem functioning and human well-being. At the same time, water is a resource under considerable pressure. Alterations in the hydrologic regime due to global climatic, demographic and economic changes have serious consequences for people and the environment (IPCC, 2012).

Human dependence on the water requires constant management of freshwater system at all geographical levels - global, regional and local. Failure in managing this resource in the past resulted in rapid depletion of water in many countries with the increase of chronic water scarcity (WWAP, 2012). Moreover, projections based on the rates of world economic growth show that water demand will increase in more than $500 \%$ in the next decades imposing a fierce competition for the available resources (FAO, 2013). The assessment of water availability for the 15 countries with the largest Gross Domestic Product (GDP), in 2000, shows that most of them are reaching the critic level (WWAP, 2012). As water was essential for the development of ancient civilizations, nowadays it can be a serious constraint for the development of many countries. This fact has increased the demand for new water resources management tools which would help building scenarios to guide public policies for water conservation at watershed level.

In Brazil, Federal Water Law 9.433 passed in 1997 and specific State laws established that watershed management is to be carried out by Watershed Committees. In spite of the legislation, however, the integrated water management is still a challenge mainly due the lack of efficient tools and technologies to support decision-making (Brasil, 2002, 2012).

In recent years a number of studies have developed spatial Decision Support Systems (DSS) for simulating ecological consequences of changes in land use at the scale of drainage basin. Most of them draw information from geographical information systems (GIS), and include multi-criteria analyses of the hydrological, ecological and economic impact of different management scenarios (Hirschfeld et al., 2005).

Studies on DSS development conducted during the last 15 years (e.g. Arinze, 1991; Marakas, 2003; Klauer et al., 2010; McCown et al., 2012) have identified more than 30 different approaches for designing and building decision support methods and systems. Interestingly enough, none of these approaches prevails and the various DSS development processes usually remain very distinct and project-specific. An interesting evaluation of Decision-Making Support Systems is given by Phillips-Wren et al. (2008).

This paper explores the integration of GIS and DSS based multi-criteria analyses as management tool for building pollution potential scenarios for Barra Bonita reservoir drainage basin. For that, the first step was to identify environmental and socio-economic variables which are known to affect reservoir water quality. Next, the information available were consisted and gathered into a GIS database to be submitted to spatial and DSS analyses. As result 182 sub-basins of the study area were classified according to their pollution potential. At the end of the analysis it was possible to identify among the variables, which were critical at sub-basin level in order to derive guidelines to reduce their impact on water quality.

\section{Material and Methods}

\subsection{Study area}

The drainage basin contributing to Barra Bonita reservoir includes the Piracicaba-Capivari-Jundiai basins (BHPCJ) and the Tietê-Sorocaba basins (BHTS), both located in the São Paulo State, as seen in Figure 1. It corresponds to $19,000 \mathrm{~km}^{2}$ and is located in one of the most populous regions in São Paulo State, Brazil. The reservoir primary role is to support hydroelectricity generation. The lake was formed by damming Tiete River and floods approximately $300 \mathrm{~km}^{2}$. At present, it is a multiple use reservoir and it is also integrated in the Mercosul navigation network of southern Brazil, an additional factor impacting its water quality (Calijuri and Santos, 2001).

The urban population of the Barra Bonita drainage basin was around 3.454.892 inhabitants in 2002. The main towns in the basin contributed at that time with $16 \%$ of the Brazilian Gross Domestic Product. It represents the most industrialized region in the country with a high productive agriculture based on sugar cane for ethanol production (Canasat, 2013). Barra Bonita reservoir has being subjected to several studies since 1963 when the hydroelectric started operation (Calijuri and Santos, 2001; Bini, 1997; Prado, 2004; Tundisi et al., 2008; Maia et al., 2008). The reservoir has attracted attention from the scientific community because of the many water quality problems faced by the hydropower company (Calijuri and Santos, 2001). Its water is classified as eutrophic during most of the year due to input of polluted water from its overpopulated and industrialized sub-basins. Therefore, it represents an excellent case study whose knowledge can be transfered to other basins in the State. 


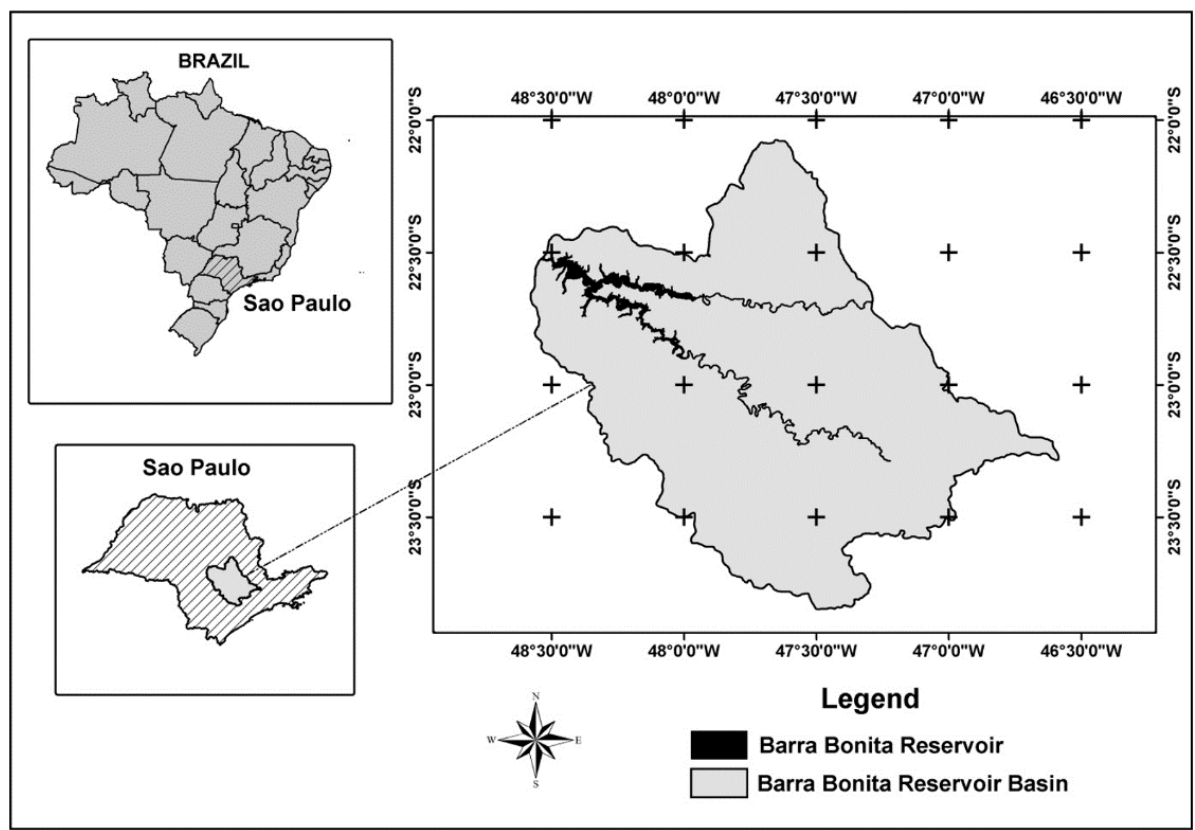

Figure 1. Location of Barra Bonita Reservoir Basin in São Paulo State - Brazil.

\subsection{Data collection and organization}

Topographic (IBGE, 2004), geomorphologic (Ponçano et al., 1981), geological (Bistrichi et al., 1981) and pedological (Oliveira, 1999) maps were acquired, digitized and integrated into a spatial database for the study area. Details on technical procedures are described in Prado (2004). These maps were used to characterize the main drainage basin physiographic variables controlling the natural polluting potential of a given area. These maps were provided at different scales and projections which were made compatible by applying a series of cartographic tools available in the Spring 3.6 software (INPE, 2004).

Data from rain gauging stations provided by the Water and Electrical Energy Department (Departamento de Águas e Energia Elétrica - DAEE) were also converted into a map describing the spatial distribution of the intensity of precipitation at sub-basin level. In order to include the impact of land/use and land cover in the drainage basin potential for pollution, Landsat/ETM+ images were used to produce a 2002 land use map for the entire basin. Details on the procedures were described in (Prado, 2004).

The output scale for the maps displaying the pollution potential scenarios was 1:250,000 with UTM (Universal Transverse Mercator) projection and Datum SAD69 (South American Datum of 1969). These maps were used to compute the variables described in Table 1. The mapping unit was the sub-basin (182 sub-basins in total) whose limits were digitalized from topographic charts using Spring 3.6 software.

Topographic maps provided information on the drainage network and watershed limits which were used to compute maps of drainage density (DD) distribution and a watershed distance. A zonal average algorithm
(INPE, 2004) was applied to create the drainage density distribution at sub-basin level.

The equation applied to calculate drainage density was (Equation 1):

$D D=\sum R / \mathrm{A}$

Where:

$\sum R$ : Rivers sum length - $\mathrm{m}$

\section{A: Sub-basins area $\left(\mathrm{m}^{2}\right)$}

The Distance Maps module provided by Spring 3.6 was applied to compute the geometric distance between the center of the each sub-basin and the nearest reservoir shore.

Seventy five (75) rain gauging stations provided the information of rainfall distribution on the drainage basin. Taking into account that not only the amount of precipitation but its frequency distribution is a key aspect for the nonpoint source inputs to the reservoir (Prado, 2004), the annual precipitation coefficient of variation of each rain station was computed as a proxy of the rain distribution along the year. The rational for using the coefficient of variation of precipitation as proxy is that the uniform precipitation along the year would result in small standard deviation values while rain concentration in one or two months would result in high coefficient of variation (CV). The CV for each station was submitted to spatial analysis using linear kriging (Bailey and Gatrell, 1995) and assigned for each sub-basin using the zonal average (INPE, 2004).

Cloud-free ETM+ Landsat images were used for mapping land use in 2002. Image spatial resolution was re-sampled to $60 \mathrm{~m}$ by $60 \mathrm{~m}$ for reducing the processing time due to the size of the region. The images were submitted 
Table 1. Maps, tabular data, variables and respective descriptions, used in the model.

\begin{tabular}{|c|c|c|}
\hline Maps and tabular data & Variable & Description \\
\hline Landsat images /ETM+ & $\begin{array}{l}\text { Land use / } \\
\text { land cover }\end{array}$ & $\begin{array}{l}\text { Land use type and percentage will exert direct influence on } \\
\text { soil quality, erosion processes, sediment transport, point } \\
\text { and nonpoint pollution sources. This variable offers large } \\
\text { impact on the quantity and quality of nutrient input into water } \\
\text { resources. }\end{array}$ \\
\hline \multirow[t]{2}{*}{$\begin{array}{l}\text { Topographic map } \\
(1: 250,000)\end{array}$} & $\begin{array}{l}\text { Sub-basin } \\
\text { drainage } \\
\text { density }\end{array}$ & $\begin{array}{l}\text { Describes basin potential for transferring watershed pollution } \\
\text { output into the fluvial system. The higher the drainage density, } \\
\text { the larger is the transference potential. }\end{array}$ \\
\hline & $\begin{array}{l}\text { Sub-basin } \\
\text { distance } \\
\text { to reservoir }\end{array}$ & $\begin{array}{l}\text { Describes the potential for dilution or deposition of the input } \\
\text { from the watershed. The higher is the distance between } \\
\text { the watershed and the reservoir, the shorter is the pollution } \\
\text { potential. }\end{array}$ \\
\hline $\begin{array}{l}\text { Pedology map } \\
(1: 250,000)\end{array}$ & Pedology & $\begin{array}{l}\text { Soil characteristics of a watershed will influence infiltration, } \\
\text { percolation, absorption and runoff that carry pollutants to } \\
\text { water bodies, as well as erosion, among others. }\end{array}$ \\
\hline $\begin{array}{l}\text { Geology map } \\
(1: 250,000)\end{array}$ & Geology & $\begin{array}{l}\text { This variable relates to the composition of rocks. Depending } \\
\text { on the type of rocks different elements can reach the water } \\
\text { bodies. The geology also controls water infiltration and } \\
\text { groundwater contamination. }\end{array}$ \\
\hline $\begin{array}{l}\text { Geomorphology map } \\
(1: 250,000)\end{array}$ & Geomorphology & $\begin{array}{l}\text { This is a factor whose natural features such as terrain slope, } \\
\text { slope geometry and dimensions, among others, have great } \\
\text { influence on the runoff, and thus the transport of pollutants to } \\
\text { the water bodies. }\end{array}$ \\
\hline $\begin{array}{l}\text { Precipitation data from } \\
75 \text { stations }\end{array}$ & $\begin{array}{l}\text { Precipitation } \\
\text { Coefficient } \\
\text { of Variation }\end{array}$ & $\begin{array}{l}\text { The intensity of rain will be a determining factor in the } \\
\text { processes of runoff and erosion and hence the supply of } \\
\text { nutrients and sediments reaching the reservoir. }\end{array}$ \\
\hline
\end{tabular}

to the following processing previous to the classification: atmospheric correction (Chavez Junior, 1988, 1996), geometric correction, mosaic building and mosaic equalization. The mosaics were segmented using area and similarity thresholds of 10 and 20 respectively. The segmented images were then submitted to a region based supervised classification using the Bhattacharya Distance classifier with a classification threshold of $90 \%$ (INPE, 2004). The classification accuracy figures are summarized in Table 2. The supervised classifier was trained using 98 samples defined during a ground-truth mission in the study area (Figure 2). Eleven land use/ land cover classes were mapped for the 2002 images. The area $\left(\mathrm{km}^{2}\right)$ of each class using Spring tools (Table 3). Prado (2004) provides more information about the procedures for producing land use/land cover maps.

\subsection{Data analysis and modeling}

In this study a Multi-criteria Analysis (MCA) was used as decision support system (DSS). The MCA is a decision-making tool developed to deal with complex problems. In situations where multiple criteria are involved, there is a need of well-structured-decision-making process to be followed. There are several methods for implementing MCA such as ranking, rating and pair-wise comparisons. In this study, the MCA was implemented with the aid of algebra mapping language available in the Spring
Table 2. Precision values in percentage from land use/land cover classification.

\begin{tabular}{cc}
\hline $\begin{array}{c}\text { Precision of the images } \\
\text { classification }\end{array}$ & From 2002 image \\
\hline Overall performance & $90.65 \%$ \\
Confusion average & $5.61 \%$ \\
Omission average & $3.74 \%$ \\
\hline
\end{tabular}

Table 3. Land Use/Land Cover area of classes obtained from images classification in 2002.

\begin{tabular}{cc}
\hline Land use/land cover classes & Area 2002 $\mathbf{( k m}^{\mathbf{2}} \mathbf{~}$ \\
\hline Urban area & 1286.49 \\
Bare soil & 1804.96 \\
Pasture & 5143.73 \\
Sugar cane & 4917.72 \\
Annual crop & 878.80 \\
Perennial crop & 247.65 \\
Natural vegetation & 2665.05 \\
Reforestation & 581.50 \\
Macrophytes & 19.23 \\
Cloud and shadow & 1290.12 \\
Drainage & 329.18 \\
Total & 19164.43 \\
\hline
\end{tabular}




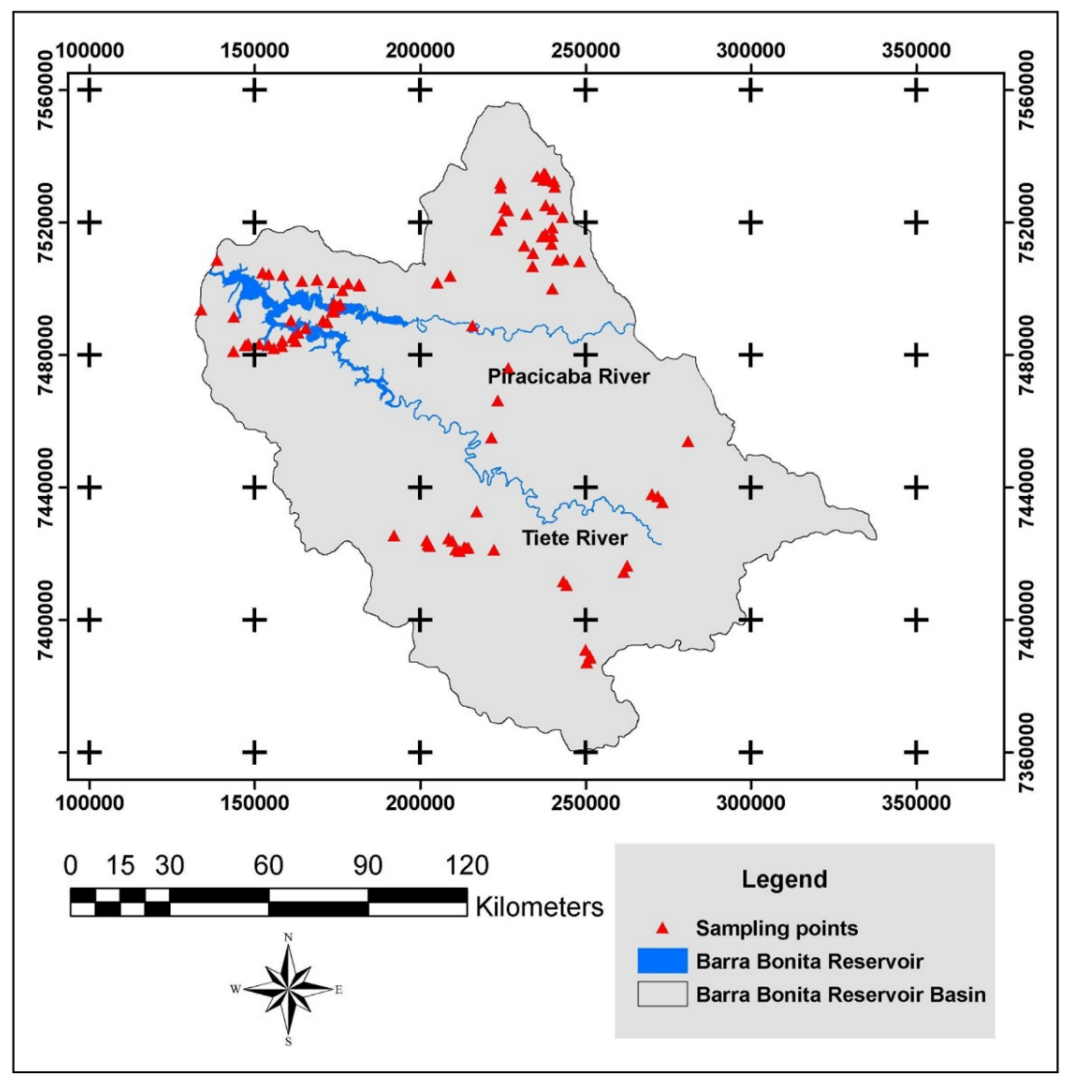

Figure 2. Location of the ground truth samples used in the supervised classification of the 2002 ETM image.

3.6 software. This language (Language geographical space based in algebra - called LEGAL in Spring) is a direct-manipulation query language that allows building complex combination of maps by applying algebraic expressions. The combination of multiple maps (information layers) relies on the assignment of weights for each layer according to multiple criteria.

The weighing criterion depends on the evaluation criteria incorporated into the decision model. These preferences are expressed in priorities or weights indicating the importance of a given criterion (environmental or socioeconomic factor) relative to the other. Uncertainty and subjectivity that so often arises in planning situations were taken care of by performing sensitivity analysis and observing changes in results with simultaneous alteration in weights of different variables.

In the present study the variables (criteria) were weighted according to their importance for each sub-basin, assuming that each one has a specific role as pollution source according to their natural setting (geology, soil, geomorphology, drainage density, precipitation rates, geographic distance to the reservoir) as well as to their land use and cover. Specialists (experts) helped to attribute weights to each variable to reduce the uncertainty and subjectivity in the process.

Each criterion was organized and classified according five levels of pollution potential (Very Low, Low, Medium,
High and Very High) and the experts attributed weights according to each class. Four different scenarios were modeled based on the assumption that the land use exerts the highest influence on the pollution input to the Barra Bonita reservoir, since features as soil, geomorphology, geology, pedology, precipitation and geographic distance of each sub-basin to reservoir did not undergo changes in short time spans such as the period under study. Because of this assumption, the weights of all variables except land use were kept constant at each run. The weights of land use were increased at each new run. Table 4 shows the four expressions applied to model different scenarios for assessing the impact of sub-basins on Barra Bonita reservoir water quality (S1 to S4).

The weight attributed to land use impact on the pollution potential was increased from Scenario 1 to 4 . Table 5 presents criterion (variable) classes and respective weights.

\section{Results}

The output from the weighting process is shown on Figure 2a-g. Each variable was classified into 5 classes according to its pollution potential to the Barra Bonita reservoir. Figure 3 presents the spatial distribution of the pollution potential for each variable used to modeling each of the classes. 
Figure $4 \mathrm{a}-\mathrm{d}$ presents the main simulation results (Scenario 1 to 4 ) and Table 6 presents the area of each potential pollution class.

\section{Discussion}

Figure 3 shows that the potential of each sub-basin for polluting the reservoir varies widely when different criteria are used. When only land use was analyzed to assess sub-basin pollution potential, less than $50 \%$ of the basin is classified as highly threatening to water quality. It is possible to observe that almost the entire spectra of land use pollution potential spanning from Very High to Low, occur in the basin. The Low potential was related to the Land Conservation Unit (APA Jundiaí/Cabreuva), which represents the unique area where natural vegetation is still present on the basin. If the pedology criterion is analyzed, the basin is totaly unsuitable for reservoir construction because the soils are very susceptible to erosion. In the region where it operates the Barra Bonita reservoir, the main material released into rivers consists of clay and silt in

Table 4. Scenarios of pollution potential of the Barra Bonita reservoir catchment basin. Selected themes: Drainage Density (T1); Sub-basin distance to the reservoir (T2), Precipitation Coefficient of Variation (T3), Pedology (T4), Geology (T5), Geomorphology (T6) and Land Use/land cover (T7); W is the Weight applied to each theme.

\begin{tabular}{cl}
\hline Scenarios & \multicolumn{1}{c}{ Simulation } \\
\hline $\mathrm{S} 1$ & $((\mathrm{~T} 1 * \mathrm{~W} 1)+(\mathrm{T} 2 * \mathrm{~W} 3)+(\mathrm{T} 3 * \mathrm{~W} 2)+(\mathrm{T} 4 * \mathrm{~W} 2)+(\mathrm{T} 5 * \mathrm{~W} 2)+(\mathrm{T} 6 * \mathrm{~W} 2)+(\mathrm{T} 7 * \mathrm{~W} 3))$ \\
$\mathrm{S} 2$ & $((\mathrm{~T} 1 * \mathrm{~W} 1)+(\mathrm{T} 2 * \mathrm{~W} 3)+(\mathrm{T} 3 * \mathrm{~W} 2)+(\mathrm{T} 4 * \mathrm{~W} 2)+(\mathrm{T} 5 * \mathrm{~W} 2)+(\mathrm{T} 6 * \mathrm{~W} 2)+(\mathrm{T} 7 * \mathrm{~W} 4))$ \\
$\mathrm{S} 3$ & $((\mathrm{~T} 1 * \mathrm{~W} 1)+(\mathrm{T} 2 * \mathrm{~W} 3)+(\mathrm{T} 3 * \mathrm{~W} 2)+(\mathrm{T} 4 * \mathrm{~W} 2)+(\mathrm{T} 5 * \mathrm{~W} 2)+(\mathrm{T} 6 * \mathrm{~W} 2)+(\mathrm{T} 7 * \mathrm{~W} 5))$ \\
$\mathrm{S} 4$ & $((\mathrm{~T} 1 * \mathrm{~W} 1)+(\mathrm{T} 2 * \mathrm{~W} 3)+(\mathrm{T} 3 * \mathrm{~W} 2)+(\mathrm{T} 4 * \mathrm{~W} 2)+(\mathrm{T} 5 * \mathrm{~W} 2)+(\mathrm{T} 6 * \mathrm{~W} 2)+(\mathrm{T} 7 * \mathrm{~W} 7))$ \\
\hline
\end{tabular}

Legend. T1, T2, T3, T4, T5, T6 are the selected themes, respectively: Drainage Density; Sub-basin distance to the reservoir, Precipitation Coefficient of Variation, Pedology, Geology, Geomorphology and Land Use/land cover. W is the Weight applied to each theme.

Table 5. Variables, classes and their weights.

\begin{tabular}{|c|c|c|}
\hline Variables & Classes & Weight \\
\hline \multirow[t]{9}{*}{ Land use / land cover } & Urban area & Very High \\
\hline & Bare soil & Very High \\
\hline & Pasture & High \\
\hline & Sugar cane & High \\
\hline & Annual crop & Medium \\
\hline & Perennial crop & Low \\
\hline & Natural vegetation & Very Low \\
\hline & Reforestation & Low \\
\hline & Macrophyte & Medium \\
\hline \multirow[t]{5}{*}{ Sub-basin drainage density $\left(\mathrm{m} \mathrm{m}^{-2}\right)$} & $0.0000000-0.0002056$ & Very Low \\
\hline & $0.0002056-0.0004042$ & Low \\
\hline & $0.0004042-0.0006028$ & Medium \\
\hline & $0.0006028-0.0008014$ & High \\
\hline & $0.0008014-0.0010000$ & Very High \\
\hline \multirow[t]{5}{*}{ Sub-basin distance to reservoir (m) } & $88800-111000$ & Very Low \\
\hline & $6600-88800$ & Low \\
\hline & $44400-66600$ & Medium \\
\hline & $22200-44400$ & High \\
\hline & $0000-22200$ & Very High \\
\hline \multirow[t]{8}{*}{ Pedology (FAO, 2006) } & Acrisol & Very High \\
\hline & Ferralsol & High \\
\hline & Phaeozem & Low \\
\hline & Planosol & Medium \\
\hline & Gleysol & Very Low \\
\hline & Cambisol & Medium \\
\hline & Fluvisol and Arenosol & Medium \\
\hline & Leptosol & Very High \\
\hline
\end{tabular}


Table 5. Continued...

\begin{tabular}{|c|c|c|}
\hline Variables & Classes & Weight \\
\hline \multirow[t]{18}{*}{ Geology } & Alluvion & Very low \\
\hline & Rio Claro Formation & Very Low \\
\hline & Itaqueri Formation & Medium \\
\hline & Marília Formation & Low \\
\hline & $\begin{array}{l}\text { Serra Geral Formation and } \\
\text { Basic Intrusive Rocks }\end{array}$ & High \\
\hline & Botucatu Formation & Very Low \\
\hline & Pirambóia Formation & Medium \\
\hline & Corumbataí Formation & Very High \\
\hline & Teresina Formation & Very High \\
\hline & Serra Alta Formation & Very High \\
\hline & Irati Formation & Very High \\
\hline & Tatuí Formation & High \\
\hline & Itararé Formation & Low \\
\hline & Post tectonic granite suites & Very Low \\
\hline & São Roque & High \\
\hline & Amparo Complex & High \\
\hline & Undifferentiated granite suites & High \\
\hline & Syntectonic granite suites & High \\
\hline \multirow[t]{15}{*}{ Geomorphology } & Basalt plateau & Very High \\
\hline & Local canyon watersheds & Very High \\
\hline & Festooned cliffs & Very High \\
\hline & Alluvial plain & Very Low \\
\hline & Plateau & Very Low \\
\hline & Wide hills & Very Low \\
\hline & Medium hills & Low \\
\hline & Small elongated hills and ridges & Medium \\
\hline & Round hills & Medium \\
\hline & Elongated and parallel small hills & Medium \\
\hline & Flat hills & Medium \\
\hline & Mar de Morros & High \\
\hline & Parallel hill & High \\
\hline & Hills with restricted ridges & Very High \\
\hline & Elongated ridges & Very High \\
\hline
\end{tabular}

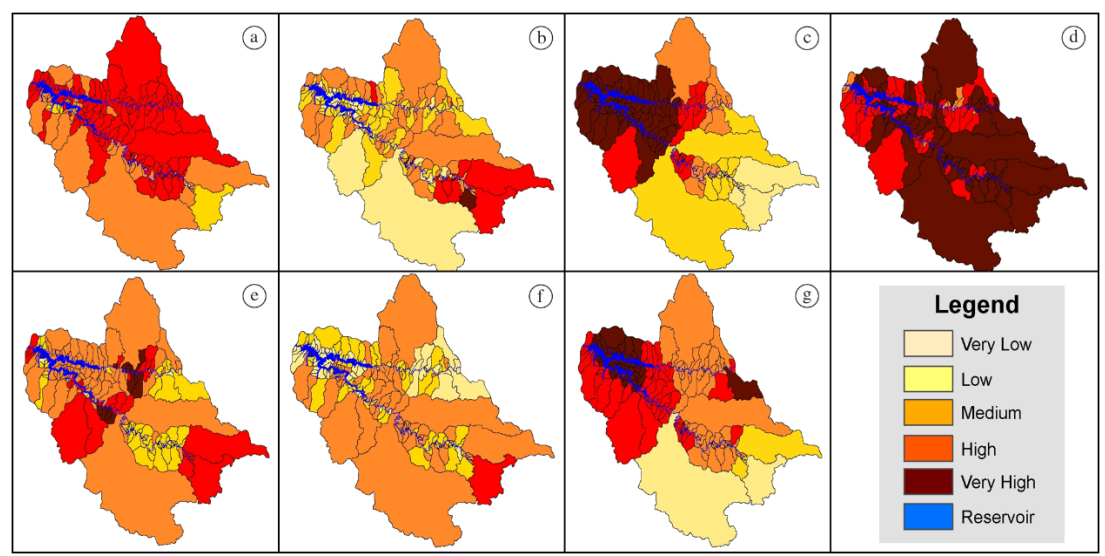

Figure 3. Spatial distribution of the potential pollution for each variable (criterion) used to modeling: a - Land use/land cover, $\mathrm{b}$ - Drainage density, c - Sub-basin distance to reservoir, d - Pedology, e - Geology, f - Geomorphology and g - Precipitation coefficient of variation. 
suspension. These fine sediments are carried in suspension over long distances and reach therefore the interior of the reservoir. They can remain there for a long time. The polymitic system reservoir prevents rapid settling of this material (Calijuri et al., 2002).

In fact many studies in recent decades has shown that the state of degradation of water quality in Barra Bonita reservoir has been intense, being considered as eutrophic (Calijuri and Santos, 2001; Prado, 2004; Maia et al., 2008; Tundisi et al., 2008). Figure 3, therefore, highlights the importance of the multi-criteria analyses as water resources management tool, because it allows to choose conservation practices.

It is clear in Figure 4 that the higher is the weight of the land use, the higher is the basin potential for pollution. From Scenarios 1 towards 4 the area classified as Very Low potential pollution decreases and the Very High increases. The larger the weight assigned to land use and land cover is, the larger is the sub-basin potential for transferring pollutants to Barra Bonita reservoir. The potential of water pollution increases gradually along simulations until all sub-basins change to maximum potential (Very High). In the case of Low, Medium and High classes, the behavior of pollution potential was variable (increasing or decreasing) but not intensively (Table 6). However, it was observed that the area occupied by the Low class tends to be reduced when the weights assigned are Very High, as in the case of S4. The Medium class, however, remained fairly stable throughout simulations.

The results obtained after modeling were quite consistent considering that the sub-basins associated with High or Very High classes are predominantly those near the reservoir. In fact, the variable sub-basin distance to the reservoir shoreline contributed to these results. The type of land use/land cover and the soils susceptible to erosion (argisols) also contributed to this result, not to mention the precipitation coefficient of variation that is higher near the reservoir.

According to Kuhnle et al. (1996) the decision support for suitable land management must rely on a better knowledge about the impact of land use changes upon the water and sediment movement through the drainage basin. In this context, maps as in Figure 4 give support to select sub-basins in need of more strict conservation practices.

The main advantage of these modeling techniques is to be able to simulate different scenarios quickly prospecting
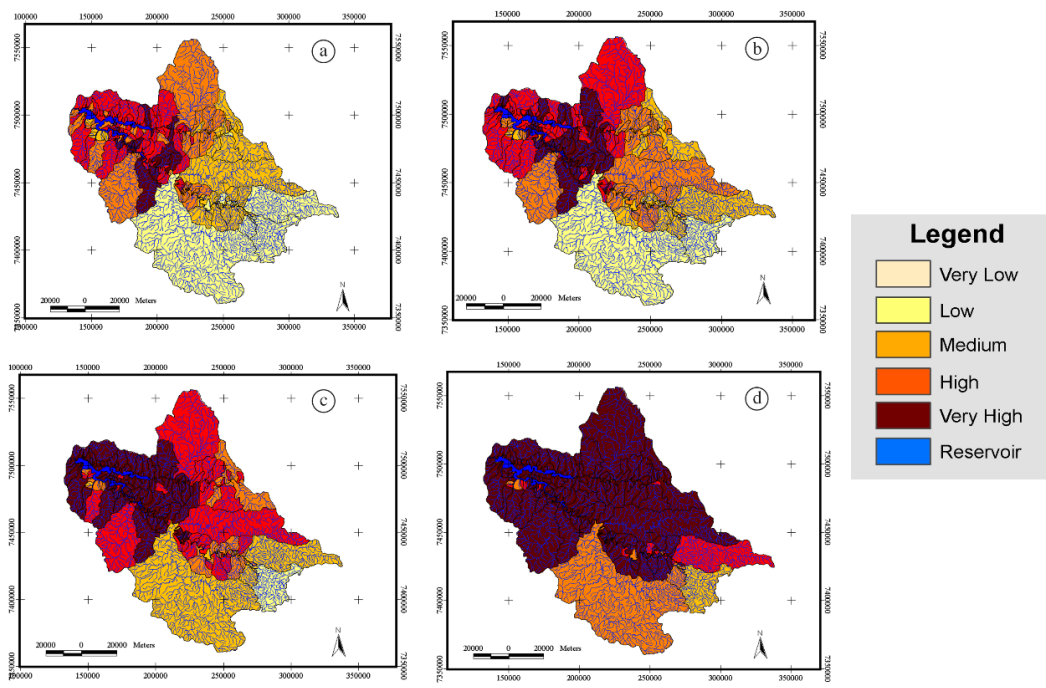

Figure 4 (a to d). Scenarios 1 to 4 resulted from modeling, respectively.

Table 6. Area occupied by the classes with different levels of pollution potential according to different proposed scenarios (S).

\begin{tabular}{crrrr}
\hline \multirow{2}{*}{$\begin{array}{c}\text { Levels of pollution } \\
\text { potential class }\end{array}$} & \multicolumn{4}{c}{ Classes area $\left.\mathbf{( k m}^{\mathbf{2}}\right)$} \\
\cline { 2 - 5 } & $\mathbf{S 1}$ & $\mathbf{S}$ & \multicolumn{1}{c}{$\mathbf{S 3}$} & $\mathbf{S 4}$ \\
\hline Very Low & 6471.04 & 5074.22 & 739.19 & 5.13 \\
Low & 3836.55 & 2576.38 & 5677.86 & 741.92 \\
Medium & 4456.41 & 4546.38 & 1498.67 & 4567.38 \\
High & 2978.33 & 4182.81 & 6435.83 & 1334.49 \\
Very High & 1071.60 & 2349.94 & 4462.38 & 12165.01 \\
Drainage & 350.50 & 350.50 & 350.50 & 350.50 \\
Total & 19164.43 & 19164.43 & 19164.43 & 19164.43 \\
\hline
\end{tabular}

Legend: $\mathrm{S}$ is Scenario. 
situations far from the reality. As an example, one could simulate what would be the change in the area occupied for different pollution potential classes if new conservation areas were stablished in the drainage basin. Another advantage of simulation of scenarios is its low cost compared to in situ experiments in a region with the complexity and size of the area under investigation (Marakas, 2003).

Machado et al. (2003), for instance, carried out a study in the Ribeirão dos Marins (Piracicaba, SP) simulating the impact of land use changes in sediment production during 1999/2000. The authors also concluded that it is fundamental to approach the drainage basin landscape globally as areas environmentally sensitive, where on should choose between enforcing land use changes or erosion control practices, and not only the protection provided by the riparian vegetation.

\section{Conclusions}

Despite the subjectivity involved in the processes of weighing, the multi-criteria analysis model used in this research proved to be a simulation tool for creating scenarios at sub-basin level to support suitable land use polices for water resources conservation. This method is useful for identifying priority areas for intervention in terms of regulation of land use, restoration of degraded areas, reforestation, pesticide control, erosion control, reduction of diffuse pollution sources.

The simulation results also show that the Barra Bonita drainage basin is naturally prone to pollution due to the high drainage density gathering the overland flow into the river channels and due to the easily erodible soils. The intense conversion of natural vegetation (which offered protection to erosion) into cropland turned the basin into an area where $20 \%$ of the sub-basin has Very High pollution potential even in the milder scenario, which is the scenario just after the land use conversion. As the area is successively occupied for agriculture and conservation practices are ignored, soil degradation increases, and so, the pollution potential. One hypothesis can be that $\mathrm{S} 1$ correspond to the sub-basin pollution potential in 2002, and with successive years of agricultural and urban land use, S4 might well reflect the present pollution potential. This type of hypothesis maybe easily tested on the ground by acquiring water samples and determining concentration of pollutants in critical areas.

In terms of pollution input to the Barra Bonita reservoir, it is important to mention that the critical sub-basins are closer to the reservoir and located in flat areas, where the land use is more intensive related to agricultural and urban activities. These sub-basins need more attention in a water resources planning.

\section{Acknowledgements}

The authors thank the Fundação de Amparo à Pesquisa do Estado de São Paulo (FAPESP), Process number 00/102682-1 for the financial support and the Centre for
Water Resources and Applied Ecology - EESC - University of São Paulo and the National Institute for Space Research (INPE) for technical support and infrastructure.

\section{References}

ARINZE, B., 1991. A contingency model of DSS development methodology. Journal of Management Information Systems, vol. 8, no. 1 , p. $149-166$

BAILEY, TC. and GATRELL, AC., 1995. Interactive spatial data analysis. Harlow: Addison Wesley Longman Limited.

BINI, LM., 1997. Spatial variation of some limnological parameters in Barra Bonita reservoir (São Paulo, Brazil): a geostatistical approach. Verhandlungen des Internationalen Verein Limnologie, vol. 26, no. part.2, p. 229-231.

BISTRICHI, CA., CARNEIRO, CDR., DANTAS, ASL., PONÇANO, WL., CAMPANHA, GAC., NAGATA, N., ALMEIDA, MA., STEIN, DP., MELO, MS. and CREMONINI, AO., 1981. Mapa geológico do Estado de São Paulo - Escala 1:500.000. São Paulo: SICCT/Pró-Minério/DCET/Instituto de Pesquisas Tecnológicas -IPT.

Brasil. Agência Nacional de Águas - ANA, 2002. Evolução da Organização e Implementação da Gestão de Bacias no Brasil. Brasília: ANA.

Brasil. Agência Nacional de Águas - ANA, Ministério do Meio Ambiente-MMA, 2012. Conjuntura dos Recursos Hídricos no Brasil: informe 2012. Edição especial. Brasília: ANA/MMA.

CALIJURI, MC. and SANTOS, ACA., 2001. Temporal variations in phytoplankton primary production in a tropical reservoir (Barra Bonita, SP - Brazil). Hydrobiologia, vol. 445, no. 1-3, p. 11-26. http://dx.doi.org/10.1023/A:1017554829992.

CALIJURI, MC., SANTOS, ACA. and JATI, S., 2002. Temporal changes in the phytoplankton community structure in a tropical and eutrophic reservoir (Barra Bonita, SP - Brazil). Journal of Plankton Research, vol. 24, no. 7, p. 617-634. http://dx.doi. org/10.1093/plankt/24.7.617.

CANASAT, 2013. Monitoramento da cana-de-açúcar via imagens de satélite. Área cultivada com cana-de-açúcar por município. Available from: $<$ http://www.dsr.inpe.br/laf/canasat/tabelas.html $>$. Access in: 5 Apr. 2013.

CHAVEZ JUNIOR PS., 1988. An improved dark-object subtraction thechnique for atmospheric scattering correction of multispectral data. Remote Sensing of Environment, vol. 24, no. 3, p. 459-479. http://dx.doi.org/10.1016/0034-4257(88)90019-3.

CHAVEZ JUNIOR, PS. 1996. Image-based atmospheric corrections revisited and improved. Photogrammetric Engineering and Remote Sensing, vol. 62, p. 1025-1036. $</ \mathrm{jrn}>$.

FALKENMARK, M. and WIDSTRAND, C., 1992. Population and water Resources: a delicate balance. Washington: Population Reference Bureau. Population Bulletin.

Food and Agriculture Organization of the United Nations - FAO, 2006. World reference base for soil resources. Roma: FAO/ISSS/ ISRIC. World Soil Resources Reports, no. 103.

Food and Agriculture Organization of the United Nations - FAO, 2013. AQUASTAT. FAO. Available from: <http://www.fao.org/ nr/aquastat>. Access in: 5 Apr. 2013. 
HIRSCHFELD, J., DEHNHARDT, A and DIETRICH, J., 2005. Socioeconomic analysis within an interdisciplinary spatial decision support system for an integrated management of the Werra River Basin. Limnologica, vol. 35, no. 3, p. 234-244.

Instituto Brasileiro de Geografia e Estatística - IBGE, 2004. Malha Digital Municipal na escala 1:250.000. Available from: $<$ http:// www.ibge.gov.br/bda/pesquisas/pam>. Access in: 5 Apr. 2013.

Instituto Nacional de Pesquisas Espaciais - INPE, 2004. Manuais do Sistema de Processamento de Informações Georreferenciadas (SPRING). Available from: <http://www.dpi.inpe.br/spring/ portugues/manuais.html>. Access in: 5 Apr. 2013.

Intergovernamental Panel on Climate Change - IPCC, 2012. Managing the risks of extreme events and disasters to advance climate change adaptation. Cambridge: Cambridge University Press. Special Report of the Intergovernmental Panel on Climate Change.

KLAUER, B., RODE, M., FRANKO, U., MEWES, M. and SCHILLER, J., 2010. Decision support for the selection of measures according to the requirements of the EU water framework directive. UFZ-Diskussionspapiere, no. 2/2010.

KUHNLE, RA., BINGER, RL., FOSTER, GR. and GRISSINGER, EH., 1996. Effect of land use changes on sediment transport. Water Resources Research, vol. 32, no. 10, p. 3189-3196. http:// dx.doi.org/10.1029/96WR02104.

MACHADO, RE., VETORAZZI, CA. and XAVIER, AC., 2003. Simulação de cenários alternativos de uso da terra em uma microbacia utilizando técnicas de modelagem e geoprocessamento. Revista Brasileira de Ciencia do Solo, vol. 27, no. 4, p. 727-733. http:// dx.doi.org/10.1590/S0100-06832003000400017.

MAIA, JL., MAUAD, FF. and ALBERTIN, LL., 2008. Uso de geotecnologias para análise espacial da qualidade da água no Reservatório de Barra Bonita-SP. Revista Brasileira de Recursos Hidricos, vol. 13, p. 141-149.

MARAKAS, GM., 2003. Decision support systems in the 21st Century. 2nd ed. Upper Saddle River: Prentice Hall.
MCCOWN, RL., CARBERRY, PS., DALGLIESH, NP., FOALE, MA. and HOCHMAN, Z., 2012. Farmers use intuition to reinvent analytic decision support for managing seasonal climatic variability. Agricultural Systems, vol. 106, no. 1, p. 33-45. http://dx.doi. org/10.1016/j.agsy.2011.10.005.

OLIVEIRA, JB., 1999. Solos do Estado de São Paulo: descrição das classes registradas no mapa pedológico. Campinas: IAC. Boletim Científico IAC, no. 45 .

PHILLIPS-WREN, GE., MORA, M. and FORGIONNE, G., 2008. Evaluation of decision-making support systems. In ADAM, F. and HUMPHREYS, P. (Eds.). Encyclopedia of decision making and decision support technologies. New York: Information Science Reference. p. 320-328.

PONÇANO, WL., CARNEIRO, CDR. and BISTRICHI, CA., ALMEIDA, FFM. and PRANDINI, FL., 1981. Mapa geomorfológico do Estado de São Paulo - Escala 1:1.000.000. São Paulo: Instituto de Pesquisas Tecnológicas.

PRADO, RB., 2004. Análise espacial e temporal das alterações na qualidade da água do reservatório de Barra Bonita (SP) em função da dinâmica do uso da terra. São Carlos: Escola de Engenharia de São Carlos, Universidade de São Paulo. Tese de Doutorado em Ciências da Engenharia Ambiental.

TUNDISI, JG., MATSUMURA-TUNDISI, T. and ABE, DS., 2008. The ecological dynamics of Barra Bonita (Tietê River, SP, Brazil) reservoir: implications for its biodiversity. Brazilian journal of Biology $=$ Revista Brasileira de Biologia, vol. 68, no. 4, supplement., p. 1079-1098. http://dx.doi.org/10.1590/S151969842008000500015. PMid:19197478

World Bank, 2010. Sustaining water for all in a changing climate. Washington: The World Bank. World Bank Group Implementation Progress Report.

World Water Assessment Programme - WWAP, 2012. Managing Water under uncertainty and risk. 4th ed. UNESCO. World Water Development Report. Available from: <http://www.unesco.org/ new/en/naturalsciences/environment/water/wwap/wwdr/wwdr42012/>. Access in: 5 Apr. 2013. 